\title{
"GATS" dan Implikasinya terhadap Jasa Angkutan Udara Internasional Pasca Putaran Uruguay
}

\author{
Oleh : SefrianI
}

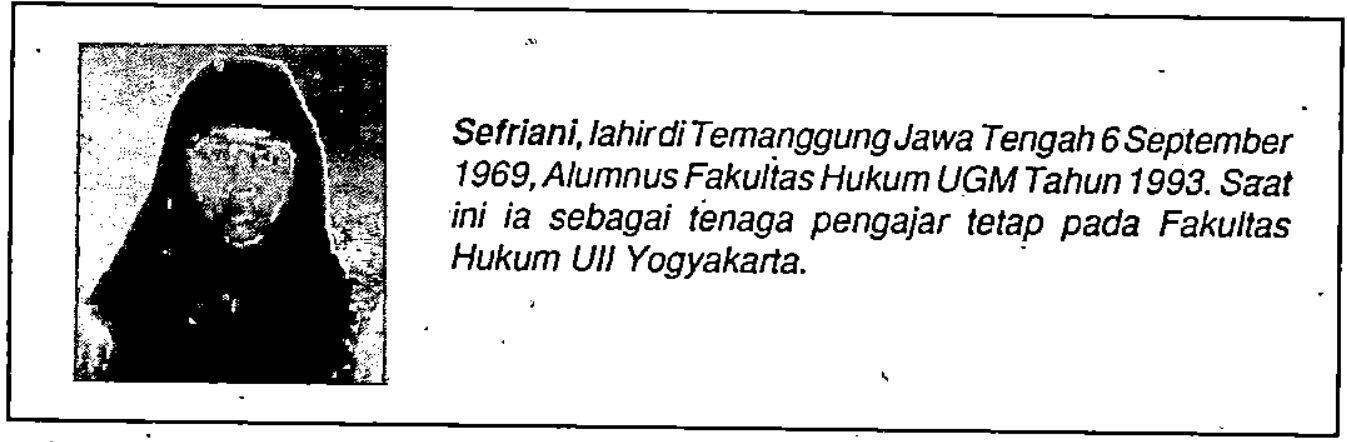

Pendahuluan

Jasa angkutan udara sudah menjadi kebutuhan yangsangat vital di seluruh dunia dewasa ini. Hemat waktu tentunya menjadi salah satu alasan pokok penggunaan jenis angkutan ini. Jasa angkutan udara intemasional tunduk pada Convention on International Civil Aviation atau yang lebih dikenal sebagai Konvensi Chicago 1994. Konvensi ini ditanda țangani pada tanggal 7 Desember 1994 dan mulai berlaku sejak 4 April 1947.

Meskipun mempunyai banyak kelemahan dan ketidakjelasan dalam muatannya, tidak dapat disangkal bahwa Konvensi Chicago 1994 cukup banyak memberikan sumbangan yang berharga pada masyarakat internasional, khususnya di sektor pengaturan jasa angkutan udara intemasional, dalam kaitannya dengan bahasan makalah ini.
Satu hal pokok yang dapat disimpulkan dari Konvensi Chicago 1994 adalah bahwa struktur hukum angkutan udara internasional berlandasrkan asas kedaulatan, kebangsaan, dan resiprositas (timbal balik). Hal.ini dapat ditunjukkan antara lain oleh ketentuan-ketentuan sebagai berikut:

1. The contracting states recognize that every state has complete and exclusive sovereignty in the airspace above its territory. ${ }^{1}$

2. Each contracting state agrees that all aircraft of the other contracting state, being aircraft not engaged in scheduled intemational air services shall have the right, subject to the observance of the terms of this Convention, to make flights into or in transit non-stop across its. territory and to make stops for non traf-

1. Ps I Konvensi Chicago 1944 
fic purposes without the necessity of obtaining prior permission, and subject to the right of the state flown over to require landing.. for reasons of savety of flight, to require aircraft desiring to proceed over regions which are inacessible or without adequate air navigation facilities to follow prescribed routes or to obtain special permission for such flight. ${ }^{2}$

3. No scheduled intemational air service may be offered over or into the teritory of contracting state, expect with the special permission or other authorization of that state... ${ }^{3}$

Meskipun untuk non-scheduled intemational air services, disepakati tidak memerlukan ijin khusus dari negara kolong (subjacent state) sebagaimana yang diatur dalam pasal 5 Konvensi Chicago dị atạs. namun pada hakekatnya azas kedaulatan, kebangsaan dan resiprositas tetap berlaku 'di sini. ${ }^{4}$ Dalam praktek, antara negara yang satu dengan yang lain mengadakan perundingan bilateral àtau multilateral, mempertukarkan hak untuk terbang di atas wilayah mereka masing-masing, 'bagi perusahaan-perusahaan penerbangan mereka.

Konvensi Chicago 1994 memang tidak memberikan penjelasan mengenaischeduled maupun non-scheduled interna-. tional air services. Namun demikian $/ n-$ ternational Civil Aviation Organization (ICAO) menjelaskan bahwa karakteristik untuk an-scheduled interiational air service adalah sebagai berikut: ${ }^{5}$

a. It passes through the airspace for the territory of more than one state.

b. 'It is performed by aircraft for the transfort of passanger, mail or cargo for remuneration in such a manner that each flight is open to use by members of public.

c. It is operated, so as to serve traffic between the same two or more point, either:

'1. according to a published time table.

2. with flights so reguler on frequent that they constitute a recognisably systematic series.

Adapun K. Martono, pakar hukum udara Indonesia memberikan karakteristik bagi non-scheduled international air service. ${ }^{6}$

1. Penerbangan tidak dilakukan menurut jadwal penerbangan yang terprogram. Kalaupun telah diprogram, dengan syarat-syarat ketat, misalnya penerbangan musiman seperti penerbangan untuk angkutan haji.

2. Penerbangan hanya diperuntukan bagi para anggota pencharter, tidak berlaku bagi yang bukan anggota.

3. Perusahaan penerbangan hanya menerima pembelian tiket secara kolektif.

4. Penerbangan dilakukandari satu tempat ke tempat lain, dan dilarang untuk menurunkan atau mengambil penumpang di setiap pelabuhan udara pendaratan.

2. Ps 5 Konvensi Chicago 1944

3. Ps 6 Konvensi Chicago 1944

4. Peranan Direktorat Jenderal Perhiubungan Udara Dalam Usaha Memanfaatkan Ruang Udara Nasional, Seminar Ruang Udara Sebagai Aset Pembangunan, Jakarta, 11 Desember 1991, hlın. 20.

5.Priyatna Abdurrasyid, KedaulatanNegara di Ruang Udara, Pusat Penclitian hukum angkasa, Jakarta 1972.

6. K. Martono, Hukum Udara, Angkutan Udara dan Hikum Ruang Angkasa, Bandung, Alumni, 1987, him. 137-138 
Seiring dengan era globalisasi, dengan diberlakukannya ketentuanketentuan GATS, khưsusnya tentang jasa angkutan udara intemasional dalam Final Act Embodying The Result of The Uruguay Round of Multilateral Trade Negotiation, akankah menghapuskan asas kedaulatan, kebangsaan, dan resiprositas dalam Konvensi Chicago? Sejauh mana implikasi GATS terhadap jasa angkutan udara internasional? Tinjauan berikut akan mencoba mengkajinya.

\section{GATS sebagai bidang baru dalam GATT}

General Agreement on Tariffs and Trade.(GATT) merupakan perjanjian perdagangan 'multilateral yang bertujuan menciptakan perdagangan yang bebas, adil dan dapat membantu menciptakan pertumbuhan ekonomi dan pembangunan guna mewujudkan kesejahtcraan umat manusia.

Dalam kerangka GATT, perundingan-perundingan multilateral di bidang perdagangan dilakukan melalui putaran perundingan (round). Putaran Uruguay sendiri merupakan putaran ke-8 dalam sejarah pertumbuhan dan perkembangan GATT (1947-1994). Putaran ini memakan waktu terlama (8 tạhun) dibandingkan putaran-putaran sebelumnya. Hal ini antara lain karena dalam putaran ini dibahas permasalahanpermasalahan yang jauh lebih kompleks dibanding putaran-putaran sebelumnya, yang hanya berkisar masalah hambatan perdagangan seperti tarif (tariff Barrier) dan non tarif (non-tariff barrier).

General Agreement on Trade in Service (GATS) merupakan salah satu contoh bidang baru yang berhasil digarap dalam Putaran Uruguay. Sebenamya jauh scbelum perundingan Putaran Uruguay, kelompok negara maju sudah menginginkan agar perdagangan di bidang jasa dimasukkan dalam kerangka GATT. Hal ini dapat dipahami mengingat sektor jasa merupakan salah satu tumpuan utama perekonomian kelompok tersebut. Meskipun demikian keinginan ini sclalu mendapat tentangan dari kelompok negara berkembang yang beranggapan bahwa masuknya sckır jasa dalam kerangka GATThanya akan memberikankeuntungan pada negara-ncgara maju saja, sebaliknya bisa jadi akan mematikan usaha pengusahapengusaha negara berkembang karena belum mampu bersaing. Baru sejak paruh ke-2 dekade 1980-an, pandangan dan sikap kelompok negara berkembang mulai berubah. Negara-negara ini makin menyadari bahwa perekonomian yang berorientasi pasar adalah pilihan yang terbaik dewasa ini untuk meningkatkan kemakmuran suatu bangsa. Liberalisasi terhadap pasar jasa merupakan metode yang efektif untuk memperbaiki kualitas dan efisiensi di sektor jasa. ${ }^{7}$

GATS yang dimuat dalam lampiran 1B The Final Act Embodying The Result of The Uruguay Round of Multilateral Trade Negosiation terdiri dari 6 bagian dan 8 lampiran (Annexes). Bagian-bagian dalam GATS tersebut meliputi:

1. Ruang lingkup dan Batasan.

2. Kewajiban Umum dan Disiplin. Mengaturmasalah-masalahseperti Most Favoured Nation (MFN) Treatment,

7.Pande Radja Silalahi, Pcrdagangandalam Jasa-Jasa Sesudah putaran Uruguay, Seminar PutaranUruguay-GATT, Sekolah Tinggi Manajemen Prasetiya Mulya, Jakarta, 14-15 Juni 1994. 
Transparansi, Pengungkapan Informasi Rahasia, dan lain-lain.

3. Komitmen Spesifik.

Mengatur masalah-masalah seperti Market Acces, National Treatment, dan Komitmen tambahan.

4. Liberalisasi Bertahap.

Mengatur masalah-masalah perundingan komitmen, daftar komitmen, dan perubahan komitmen.

5. Ketentuan mengenai kelembagaan:':

Mengatur masalah-masalah konsultasi, penyelesaian sengketa dan pelaksanaan keputusannya, Dewan Perdagangan Jasa, Kerjasama Tcknis, serta Hubungan dengan Organisasi Intemasional lainnya.

6. Ketentuan Penutup.

Mengaturmasalah pengikraran manfaat, batasan, sêrta lampiran-lampiran.

Sebagai bidang yang pertama kali diintegrasikan ke dalani GATT, negaranegara anggota memaklumi bailwa liberalisasi di bidangperdagangan jasa tidak mungkin dapat direalisasikan dalam kurun waktu yang singkat. Olch karena itu, disepakati bahwa liberalisasi scktor ini merupakan suatu proses yang berkelanjutan. ${ }^{8}$. Negara-negara anggota diberi kesempatan untuk mengajukan market acess dan/atau national treatment kepada pengusaha negara lain secara bertahap, seśuai dengan perkembangan ekonomi maupun perkembangan scktorjașa yang dimaksudkan.?

\section{Annex on Air Transport Service}

Annex tentang jasa angkutan udara (Annex on Air Transport Service) merupakan salah satu diantara 8 lampiran yang ada dalam GATS. Annex ini hanya terdiri dari 6 pasal.
Pasal 2 Annex on Air Transport Service menetapkan bahwa persetujuan dalain GATS termasuk prosedur penyelesaian sengketanya tidak berlaku untuk tindakan-tindakan yang menyangkut: 1. hak lalu lintas (traffic'right), ${ }^{10}$ bagaimanapun diperolehnya, atau;

2. -jasa-jasa yang berkaitan langsung dengan pelaksanaan traffic right, kecuali $^{11}$
a. perbaikan pesawat dan perawatannya $^{12}$
b. penjualan dan pemasaran jasa angkutan udara ${ }^{13}$

\section{8. lbid \\ 9. lbid}

10. Traffic Right menurut definisi yang diberikan Annex adalah hak untukjasa/jasaberjadwal maupun tidak berjadwal untuk pengoperasian dan/ atau untuk inengangkut penumpang, barang, dan pos untuk meinperoleh penghasilan atau sewa dari, ke, di dalan atau melintasi wilayah dari suatu negara aingota, termasuk tempat-tempat yang harus dilayani, rute yang harus dijalani, jenis lalu lintas yang perlu dilakukan, kapasitas yang disediakan, tarif yang dikenakan, dan persyaratannya, dan kriteria untuk penunjukkan, perwakilan penerbangan, termasuk kriteria lain'seperti nomor, pemilikan, dan penguasaan.

\section{Paragraf 3 Aṇnex}

12. Yang dimaksud adalah aktivitas yang dilakukan pada pesawat atau bagiannya selama pesawat tersebut ditarik dari operasi dan tidak termasuk dengan disebut 'line naintenance' .

13. Yang dimaksud adalah kesempatan bagi pengangkut udara untuk menjual dan memasarkan secara bebas jasa anğkutan udaranya, termasuk scluruh aspek dari pemasaran, seperti penelitianpasar, periklanan, dan distribusi. Kegiatan-kegiatan initidak termasuk penetapan jasa perhubunganudara maupun persyaratan yang dikenakannya. 
c. jasa-jasa reservasi komputer (computer reservation system (CRS) service $^{14}$

Dari ketentuan ini dapat disimpulkan bahwa scbenamya Annex hanya berlaku untuk soft rights-nya saja. ${ }^{15}$ Adapun untuk hard rights-nya yaitu traffic rights tctap berlaku asas kedaulatan, kcbangsaan dan resiprositas, scbagaimana yang sudah terpolakan dalam Konvensi Chicago 1994.

Fasilitas penyelesaian sengketa pada WTO menurut Paragraf 4 Annex hanya dapat diterapkan apabila kewajiban atau komitmen olch negara yang bersangkutan dan bilamana prosedur penyelesaian sengketa yang disediakan dalam perjanjianperjanjian bilateral dan multilateral jasa angkutan udara sudah dipergunakan semua, atau dengan kata lain menjadi altematif terakhir.

Sebagai bagian dari GATS, scbagaimana telah dikemukakan sebelumnya, pelaksanaan ketentuanketentuan Annex adalah secara bertahap. Council for Trade in Servicc, setidaknya dalam lima tahun sekali akan melakukan peninjauan secàra periodik terhadap perkembangan dalam sektor angkutan udara ini dengan maksud untuk mempertimbangkan kemungkinankemungkinan penerapannya lebih lanjut. ${ }^{16}$

\section{Implikasi GATS terhadapjasa angkutan udara internasional}

Sejak tahap awal'perundingan, GATS memang sudah mendatangkan pro dan kontra. Di satu sisi fakta menunjukkan bahwa perekonomian berorientasi pasar mempunyai banyak kelebihan, di siṣi lain ada kekhawatiran, khususnya dari kelompok negara berkembang bahwa
GATShanya akan memberikan keuntungan pada negara-negara maju.

Berkaitan dengan jasa angkutan udara internasional, sebenarnya kekhawatiran itu tidaklah perlu terlalu berlebihan. Sebagaimana telah dikemukakan, ketentuan dalam GATS hanya berlaku untuk soft-rightsnya saja. Dengandemikian kedaulatan negara kolong (subjacent state) untuk mengatur traffic right tidak terkurangi olch keberadaan GATS, khususnya Annex on Air Transpor Scrvice. Negara kolong tetap berhak mengatur masalah pengoperasian penerbangan berjadual maupun tidak berjadūal di wilayahnya, masalah sewa, rute, tarif, sampai penunjukkan perwakilan pencrbangan seperti sebelum ada Annex. Bahkan bagian akhir dari paragrap I Annex-pun mengemukakan bahwa negaranegara anggota tetap terikat pada persetujuan bilateral/multilateral yang ada pada saat berlakunya persetujuan pendirian World Trade Organization (WTO),

Di samping itu GATS memberi kelonggaran pada masing-masing negara untuk mengajukan "market access" dan/ atau "national treatment" kepada pengusaha negara lain secara bertahap sesuai perkembangan ekonomi dan sektor jasa yang dimaksudkan. ${ }^{17}$ Dengan demikian

14. CRS Service adalah jasa yang diberikan oleh sistem komputer yang berisikan informasi tentang jadwal pengangkutan udara, tempat duduk yang tersedia, harga tiket, aturan tentang tiket, yang melalui hal ini dapat dilakukan suatu pemesanan.

15. Lihat Assad Kotaite, Multilateralism : A View From ICAO, Sebagaimana yang dikutip oleh Pablo Mendez de leon, Air Transport Law' and Policy in The 1990s, 1991, p. 91-92.

16. Paragraf 5 Annex

17. Pande radja Silalahi, op. cit 
seandainya suatu negara merasa sektór jasa àngkutan udaranya belum mampu bersaing dalam "pasar bebas", negara ini diberi kesempatan untuk tidak memberikan market access bagi pengusaha negara lain, dengan ketentuan akan meninjau Iagi kebijakan ini tiap lima tahun sekali.

Adapun terhadap 3 jenis jasa dimana diberlakukan ketentuan GATS dapat ditinjau sebagai berikut. Yang pertama adalah jasa perbaikan pesawat dan perawatannya. Jasa ini sangat vital bagi penyelenggaraan jasa angkutan udarạ. Hal ini untuk mencegah pihak pengangkut/ perusahaan-perusahaanpenerbangan dalam usahanya menekan biaya penyelenggaraan jasa penerbangan, tidak mengadakan regenerasi terhadap pesawat-pesawat tuanya, dan tentunya kurang memperhatikan keselamatan penerbangan. Dengan asumsi GATS sudah berlaku sepenuhnya, tentu hal ini akan menámbah biaya bagi perusahaan-perusahaan penerbangan negara-negara berkembang, yang belum mampu menyelenğgarakannya sendiri, dan sebaliknya memberi keuntungan pada negara-negara maju yang mempunyai teknologi tinggi di bidang ini. Suatu staridar internasional masalah kelaikan pesawat terbang ini semacam recognition of Certificates of Airworthiness ${ }^{18}$ untuk pesawat-pesawat rakitan atau buatan beberapa negara-negara berkembang scbelum dioperasikan sangatlah diperlukan.

Yangkedua mengenai penjualan dan pemasaran jasa angkutan udara. Tidak dipungkiri bahwa masalah pemasaran menduduki posisi yang sangat penting untuk menarik konsumen scbanyak mungkin menggunakan jasa angkutan penerbangannya. Ketentuan dalam Anex yang memberi kesempatan pada pengangkutan udara untuk menjual dan memasarkan secara bcbas jasa angkutan udaranya, tentu akan memacu perusahaan-perusahaan penerbangan untuk meningkatkan diri di sektor ini.

Demikian pula halnya dengan masalah CRS Service. Teknologi canggih ini sudah digunakan sejak tahun 1984 oleh 3 perusahaan penerbangan raksasa Amerika Serikat, yakni American Airline, United Airline, dan Texas Air Corporation. CRS service memudahkan pemilik mendistribusikan dan mempromosikan jasa angkutan penerbangan perusahaannya. Dengan demikian pemilik akan mempunyai kemungkinan yang lebih besar dalam penjualan tiket melalui sistemnya. Konsumenpun akan lebih mudah mendapatkan informasi tentang jadual pengangkutan udara, tempat duduk yang tersedia, harga tiket, serta aturan tentang tiket. ${ }^{19}$ Mau tidak mau, CRS service tentu sangat diperlukan bagi suatu perusahaan penerbangan dewasa ini untuk meningkatkan daya kompetitifnya. Dan tentu saja hal ini akan menguntungkan negara-riegara maju yang mempunyai teknologi tersebut, untuk memasoknya ke negara-negara berkembang.

18: Denza, Eileen, From Acrostats to.DC10s-Recognition on Cerifficates of Airworthness, dalam Essays in Air Law, edited by FRAeS, Arnold Kean CBE, Martinus Nijhoff Publishers, The Haque/ Boston/London, 1982, p. 41.

19. Maspaitella, P.F.L, Pengaruh Deregulasi Angkitan Udara Amerika Serikat Terhadap Kcbijakan Liboralisasi Angkinan Udara MEE, Usahawan No. 5 TH XXI. Mei 1992.. . 


\section{Kesimpulan}

Sudah merupakan hal yang lazim adanya pro dan kontra terhadap lahimya suatu ketentuan baru. Demikian pula halnya dengan GATS.

Suatu pelajaran berharga dapat ditarikdaripraktek yangdilakukan Amerika Serikat. Negara Paman Sam ini pada tahun 1978 meluncurkan "The Airline deregulation Act of 1978, yang menuntut adanya penggalakan, pengembangan dan pembinaan suatu sistem angkutan udara yang bertumpu pada persaingan potensial dan nyata yang dapat menghasilkan efisiensi, inovasi, tingkat harga yang rendah, serta dapat menentukan jenis, kualitas dan tarif jasa angkutan udara sendiri, tanpa campur tangan yang berari dari pemerintah.

Fakta menunjukkan bahwa deregulasi ini memberikan implikasi semskin membesamya, baik dalam armada, organisasi, maupun jaringan penerbangan industri jasa angkutan udara Amerika Serikat. ${ }^{20}$

Ketentuan GATS tentang liberalisasi di bidang jasa angkutan udara tidak merubah asas kedaulatan, kebangsaan, serta resiprositas dalam traffic right. Hanya tiga jenis jasa yang berkaitan langsung dengan pelaksanaan traffic right, dimana berlaku ketentuan-ketentuan GATS, yakni perbaikan pesawat dan pemeliharaannya, penjualan dan pemasaran jasa angkutan udara serta jasa-jasa reservasi komputer. Ketiganya memang merupakan sarana pendukung yang vital bagi suatu perusahaan penerbangan untuk tetap exist dan lebih kompetitif memasuki pasar bebas. Sampai saat ini bidang-bidang jasa tersebutmemang masih merupakan "andalan dan lahan" negara-negara maju untuk meraup keuntungan yang sebesar-besamya dari ketentuan GATS. Sehingga dapat disimpulkan bahwa negara-negara maju memang lebih banyak memperoleh keuntungan daripadanya.

Dengan berlakunya GATS nanti, negara-negara berkembang harus memacu diri, meningkatkan profesinalitas teknologi serta manajcmen perusahaan-penusahaan penerbangannya agarmampu berkompetisi di era globalisasi ini.

\section{Daftar Pustaka}

FRAeS, Amold Kean CBE, (editor), Essays in Air Law, London, Martinus' Nijhoff Publishers, 1982.

K. Martono, Ilukim Udara. Angkatan Udara, dan Hukkm Ruang Angkasa, Bandung, Alumni, 1987.

Kotaite; Assad, Multilateralism: A View from ICAO, 1991:

Maspaitclla, P.P.L. Pengaruh Deregulasi Angkatan Udara Amerika Serikat Terhadap Kebijakan Liberalisasi Angkatan Udara MEE, Usahawan No. 5 TH XXI, Mei 1992.

Pande RadjaSilalahi, Perdagangan dalamJasajasa Sesudah Putaran Uruguay, Seminar Putiran Unuguay-GATT, Sekolah Tinggi Manajemen Prasetiamulya, Jakarta, Juni 1994.

Priyatna Abdurrasyid, Kedaulatan Negara di Ruang Udara. Pusat Penelitian Hukum Angkasa. Jakarti, 1972.

Wassenbergh, H.A. Public International Law InAEra, Kluwer, Deventer, Nederlands, 1990.

20. lbid 